\title{
FILARIAL PARASITES FROM THE BLACK BEAR OF JAPAN
}

\author{
S. UNI*
}

SUMMARY. Parasitological examinations were made on the tissues and the blood of the black bears (Selenarctos thibetanus japonicus) of Japan. Three kinds of filarial parasites were found in the tissues and the blood of the hosts: Dirofilaria ursi, Tetrapetalonema (Tetrapetalonema) akitensis sp. n. and Dipetalonema (Chenofilaria) japonica sp. n. The male and the microfilaria of $D$. ursi were described from the type host animal. Japanese specimens of $D$. ursi were compared with the specimens from American black bears of Alaska and Canada, and it was found that the measurement data obtained were similar to each other. Within the subgenus Tetrapetalonema, $T$. akitensis resembled $T$. interstitium and $T$. lleswellyni of North America, but was distinguished from them by the longer esophagus and smaller microfilariae. Several other species of the same subgenus from monkeys of South America were different from T. akitensis due to the presence of the terminal nucleus of their microfilariae. Within the subgenus Chenofilaria, D. japonica closely resembled $D$. johnstoni and $D$. pearsoni of Australia, but was different from $D$. johnstoni due to the salient preesophageal cuticular ring and relatively longer tail of the female. Besides, D. pearsoni was much longer than $D$. japonica in the body length.

\section{Filaires de l'Ours brun au Japon.}

RÉSUMÉ. Des examens des tissus et du sang de l'ours brun du Japon (Selenarctos thibetanus japonicus) ont été effectués. Trois espèces de Filaires ont été observées : Dirofilaria ursi, Tetrapetalonema (Tetrapetalonema) akitensis sp. nov. et Dipetalonema (Chenofilaria) japonica sp. nov. Le mâle et la microfilaire de $D$. ursi sont, ici, décrits chez l'hôte type. Des spécimens japonais de $D$, ursi ont été comparés morphologiquement à des spécimens américains de l'ours brun de l'Alaska et du Canada. Pratiquement, aucune différence significative n'a été trouvée entre eux. Dans le sous-genre Tetrapetalonema, $T$. akitensis ressemble à $T$. interstitium et $T$. Ulesvellyni d'Amérique du Nord, mais se distingue de celles-ci par un œsophage plus long et des microfilaires plus petites. $T$. akitensis est, de plus, différente de quelques autres espèces de singes d'Amérique du Sud par l'absence d'un noyau terminal chez les microfilaires. Dans le sous-genre Chenofilaria, $D$. japonica ressemble étroitement à $D$. johnstoni et $D$. pearsoni d'Australie, mais se différencie de D. johnstoni par la présence d'un anneau préœsophagien saillant et d'une queue relativement plus longue chez la femelle. En outre, la longueur du corps est bien supérieure chez $D$. pearsoni que chez D. japonica.

\footnotetext{
* Department of Medical Zoology, Osaka City University Medical School, Osaka 545, Japan. Accepté le 8 juillet 1982 .
} 


\section{Introduction}

Yamaguti (1941) reported Dirofilaria ursi from the Japanese black bear, and since then no other filarial species have been reported any more from bears all over the world (Rogers and Rogers, 1976; Worley et al. 1976). In the present examination, a high prevalent rate of microfilaremia and three kinds of adult filarial parasites were found from 109 black bears in three different research areas of the main island of Japan. The species from tissues of the bears from Hyogo and Kyoto was Dirofilaria ursi, and two other species from Akita represented previously undescribed species of Tetrapetalonema (Tetrapetalonema) Chabaud and Bain, 1976, and of Dipetalonema (Chenofilaria) (Kou, 1958).

D. ursi was originally described in only three females by Yamaguti (1941), but the male and its microfilaria have remained undescribed in the type host animal. Therefore, the present report provides descriptions of the adults and the microfilariae of D. ursi, Tetrapetalonema (T.) akitensis sp. n. and Dipetalonema (Ch.) japonica sp. n.

\section{1 - Dirofilaria ursi Yamaguti, 1941 (fig. 2-6)}

\section{Materials and Methods}

Three Japanese black bears (Selenarctos thibetanus japonicus), one adult from Hyogo (January, 1976) and two (a dam with its young) from Kyoto (March, 1978), were examined by the author (fig. 1). Six males and two females of D. ursi were collected from two adult bears. The worms were fixed and stored in $70 \%$ ethyl alcohol. The microfilariae from the blood of the bears were examined on the blood films, fixed in alcohol and stained by Giemsa's stain. The microfilariae of this species were found in the blood films of two adult bears, but not in the young bear from Kyoto. Illustrations were made with the camera lucida drawing, and measurements were made with an ocular micrometer.

\section{Specimens deposited*}

One male and one female were deposited in the collection of the National Science Museum, Tokyo. No. NSMT-As-1440 and 1441. Five males and one female in the collection of the Department of Medical Zoology, Osaka City University Medical School.

Host: Selenarctos thibetanus japonicus (Japanese black bear).

Locality: Hyogo and Kyoto (fig. 1).

Site of infection: Perirenal adipose tissue, loose connective tissues underneath scapula.

\footnotetext{
* The material has already been reported briefly in Japanese (Uni, 1978).
} 


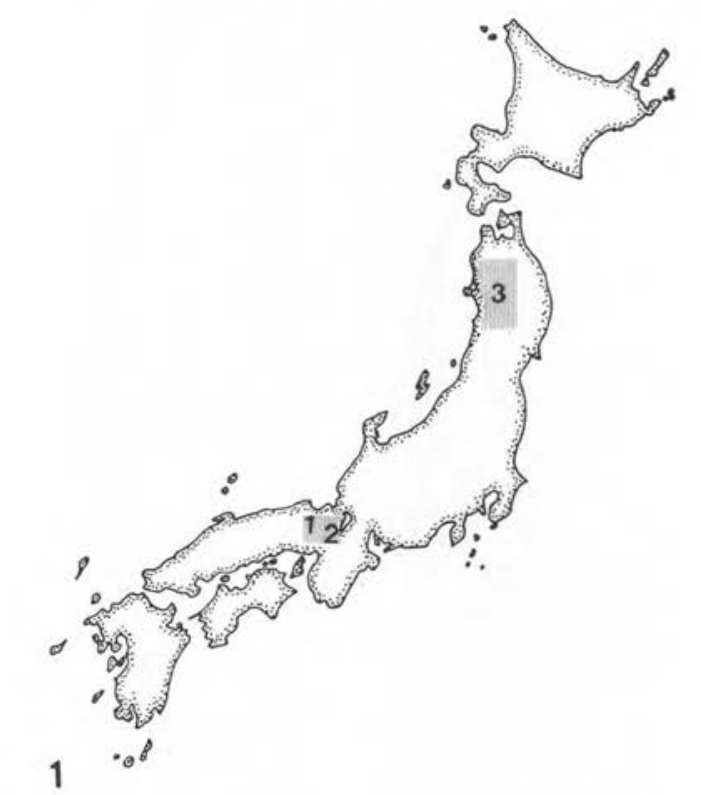

FIG. I. - Research areas for filarial parasites of bears in Japan: I, Hyogo; 2, Kyoto; 3 , Akita.

\section{Description}

General: Adult worm white filiform, with anterior end rounded, posterior part tapering and curling, and body dilatation near level of posterior end of esophagus (fig. 2). Cuticles bearing fine transverse striations and distinct longitudinal ridges. Mouth small and rounded, surrounded by 4 pairs of small submedian papillae and 1 pair of lateral amphids. Esophagus into anterior muscular and posterior glandular portions.

Male ( 6 specimens; $\mu \mathrm{m}$ ): Body $73 \mathrm{~mm}$ to $93 \mathrm{~mm}$ long, 410 to 630 wide at dilatate level and 380 to 520 wide at midbody. Nerve ring 270 to 370 from anterior end. Esophagus $1.2 \mathrm{~mm}$ to $1.5 \mathrm{~mm}$ long; muscular portion 470 to 640 long, glandular portion 790 to 900 long. Tail 60 to 100 long. Caudal alae well-developed. Numbers of pedunculate caudal papillae 7 to 10 at the left side and 6 to 9 at the right side. Besides, a single transversely elongated central papilla just before cloaca. One pair sessil papillae immediately behind cloaca and 3 pairs small slender papillae caudally on line with large peducunlate papillae ( $f i g .3)$. Phasmids ventrolaterally placed near tip of tail. Spicules unequal and dissimilar; left 500 to 610 long, right 150 to 190 long and the ratio of spicule lengths 3.2. Postdeirid left dorsolaterally at the proximal end level of retracted left spicule. Ventral ridges (according to Chitwood and Lichtenfels, 1972) at the area approximately 700 anterior to the most proximal pair of pedunculate papillae. 


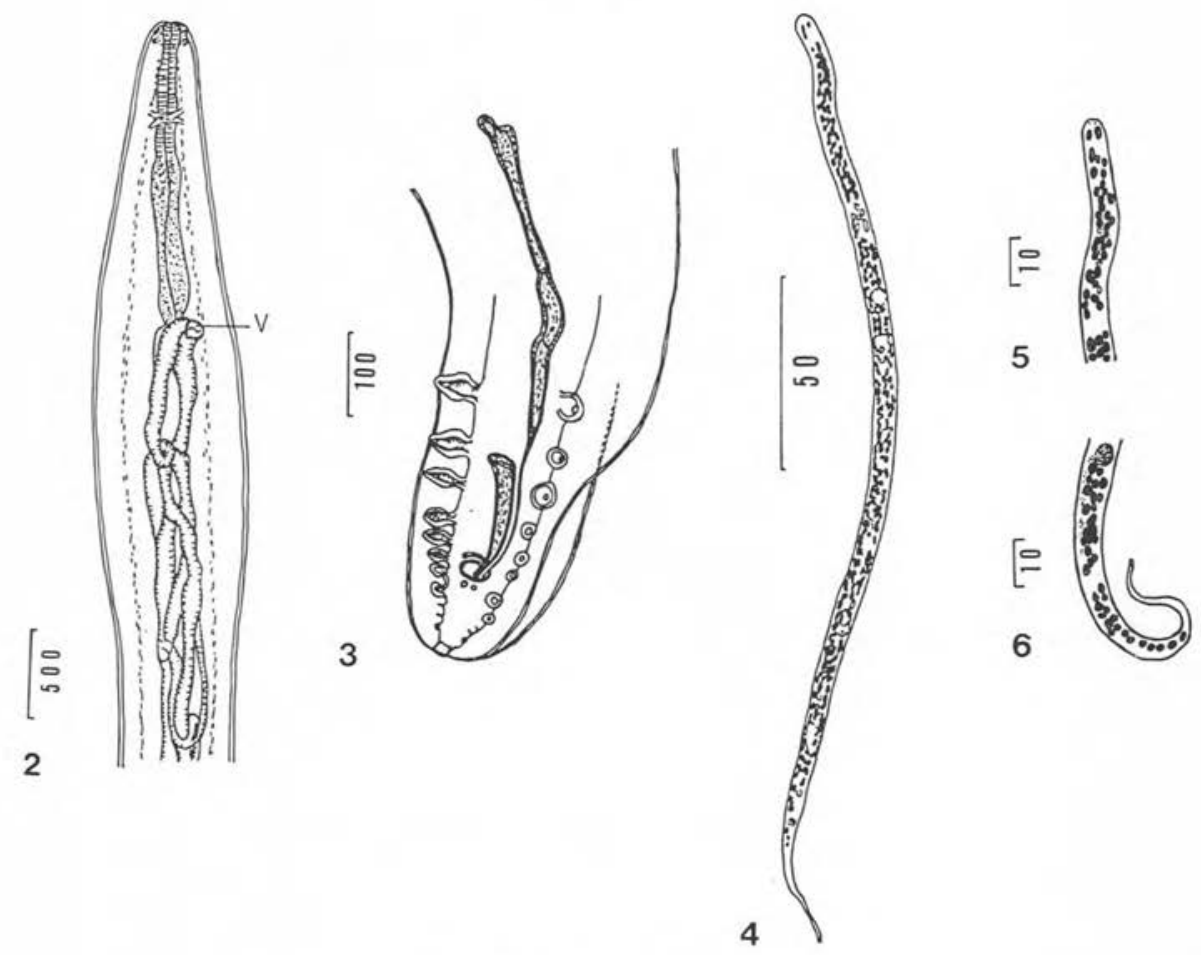

FIg. 2-6. - Dirofilaria ursi.

2. Anterior of female showing cervical dilatation. V: vulva.

3. Posterior of male.

4. Microfilaria.

5. Anterior of microfilaria showing one pair of nuclei at head space.

6. Posterior of microfilaria.

Female (2 specimens): Body $197 \mathrm{~mm}$ to $198 \mathrm{~mm}$ long and 770 to 840 wide at the dilatate level. Nerve ring 450 to 480 from anterior end. Esophagus $1.5 \mathrm{~mm}$ to $1.6 \mathrm{~mm}$ long; muscular portion 550 to $700 \mathrm{long}$, glandular portion 880 to 970 long. Vulva near esophageal-intestinal junction level, $1.7 \mathrm{~mm}$ to $3.3 \mathrm{~mm}$ from anterior end (fig. 2). Anus 170 to 180 from posterior end. Single pair of terminal papillae conspicuous and phasmidial pores near terminal papillae.

Microfilaria (10 specimens): Body 189.8 to 231.4 (225.7) long and 4.7 to 6.5 (5.2) wide, without sheath. Head space often with 2 nuclei intruding (fig. 4). Two small spots at summit of head, probably being amphids (fig. 5). Nerve ring $20.5 \%$, excretory pore $29.7 \%$, excretory cell $34.1 \%, \mathrm{G}_{1}$ cell $61.1 \%$, anal pore $73.4 \%$, last tail cell $85.8 \%$ from anterior end, respectively. Nuclear column of body 3 rows. At tail part 11 to 15 nuclei arranging in 2 to 3 rows and then reducing to single row of 6 to 9 nuclei. Terminal part without nuclei $32(14.2 \%)$ from posterior end ( fig. 6 ). 


\section{D. ursi from North America}

Specimen from Alaska

One male $D$. ursi from an American black bear, Ursus americanus americanus, in the winter den on the Levis River, Anchorage, 1959. This worm was found in only one of 219 American black bears of western Alaska by Dr. Rausch (1961), who, by his courtesy, made it available to me for examination.

Description (1 male): Body $73 \mathrm{~mm}$ long and 520 wide at dilatate level. Nerve ring 290 from anterior end. Esophagus $1.2 \mathrm{~mm}$ long. Tail 70 long. Pendunculate caudal papillae; left 8 and right. Spicules; left 510 long, right 150 long and the ratio 3.4.

Specimens from Canada

Ten males, eleven females of $D$. ursi from $U$. a. americanus and five blood smears from the hosts in Algonquin Park, Ontario, in 1975, were made available to me for comparison by courtesy of Drs. Anderson and Addison.

\section{Description}

Male (10 specimens): Body $63 \mathrm{~mm}$ to $78 \mathrm{~mm}$ long and 330 to 510 wide at dilatate level. Nerve ring 290 to 370 from anterior end. Esophagus $1.1 \mathrm{~mm}$ to $1.4 \mathrm{~mm}$ long. Tail 70 to 80 long. Pedunculate papillae; 7 to 10 at left side, and 7 to 9 at right side. Spicules; left 300 to 590 long, right 100 to 200 long, and the ratio 2.8 .

Female (11 specimens): Body $166 \mathrm{~mm}$ to $216 \mathrm{~mm}$ long and 440 to 730 wide at dilatate level. Nerve ring 340 to 420 from anterior end. Esophagus $1.3 \mathrm{~mm}$ to $1.5 \mathrm{~mm}$ long. Vulva $1.7 \mathrm{~mm}$ to $3.1 \mathrm{~mm}$ from anterior end. Anus 120 to 310 from posterior end.

Microfilaria (10 specimens): Body 234 to 285 long and 3 to 6 wide.

\section{Discussion}

The description of the male of D. ursi was reported by Anderson (1952) on the material from American black bear, U. americanus, and by Petrov and Krotov (1954) from the brown bear, U. arctos beringianus, of Sakhalin, U.S.S.R.

In the present examination the measurement data of Japanese material including the males and the microfilariae were directly compared with those of $D$. ursi from North America. No significant differences were found between the adults of them. Especially, the body dilatation of cervical part in male and female adults was seen in all specimens of Japan and also of North America. Further, it was notable that two nuclei were frequently present at the cephalic space of the microfilariae from Japan, although it was not possible to examine them on the microfilariae from Canada.

Within the genus Dirofilaria, the body dilatation was recognizable in D. acutiuscula, D. linstow and D. magnilarvatum (Lent and Teixeira de Freitas, 1937; Sonin, 1975; Price, 1959), but unrecognizable in D. immitis and D. roemeri (Uni, 1978; Johnston and Mawson, 1938). Thus, this feature may be indicative for grouping of species in Dirofilaria, even though it was not mentioned in detail in the other species. 


\section{2 - Description of two new species}

\section{Materials and Methods}

In the winter and spring seasons of 1980 and 1981, 106 black bears shot in Akita were examined for filarial parasites by the author (fig. 1). The majority of the material was the connective tissues attached to visceral organs, mainly stomach and reproductive organs, and seven individuals were examined over the whole body. Blood smears could be made on 64 blood samples including afore mentioned seven cases. Adult worms obtained were fixed and stored in $2 \%$ formol saline and microfilariae were examined in the blood smears, stained by Giemsa's stain. Microfilariae taken out from the uterus of the female worms were also examined. Illustrations and measurements of the specimens were made by the same methods as described in D. ursi. Cross-sections of the worms were made by the routine methods. The cuticle of the midbody was directly observed by metallurgical microscopy. The surface features of the worms were examined in detail by scanning electron microscopy (SEM) with the methods mentioned by Shoho and Uni (1977).

\section{(1) Tetrapetalonema (Tetrapetalonema) akitensis sp. n. (fig 7-17)}

\section{Type specimens}

Holotype: Tazawako No. 1 (female).

Muséum National d'Histoire Naturelle

Laboratoire de Zoologie, Paris. No. 264 NE.

Osaka City University Medical School, Department of Medical Zoology, Osaka.

Paratype: Three females.

Host: Selenarctos thibetanus japonicus (Japanese black bear).

Locality: Tazawako (type locality), Akita, Japan, and also Fujisato and Ani, Akita.

Site of infection: Adipose tissues around stomach and kidney, in the mesentery and on the serous membrane of uterus.

Other specimens deposited: Microfilariae (two slides of the blood smears).

Fig. 7-I7. - Tetrapetalonema (T.) akitensis sp. n.

7. Anterior of female.

8. Cephalic extremity of female.

9. Posterior of female.

10. Posterior extremity of female showing four lappets.

I I. Subcuticular markings (*) of posterior of female. $\times$ I60.

12. Transverse striations of cuticle by SEM. $\times 4.000$.

13. Lappets of posterior extremity by SEM. $\times 1,200$.

I4. Cross-section of midbody of female.

I5. Microfilaria.

I6. Anterior of microfilaria.

I. Posterior of microfilaria. 

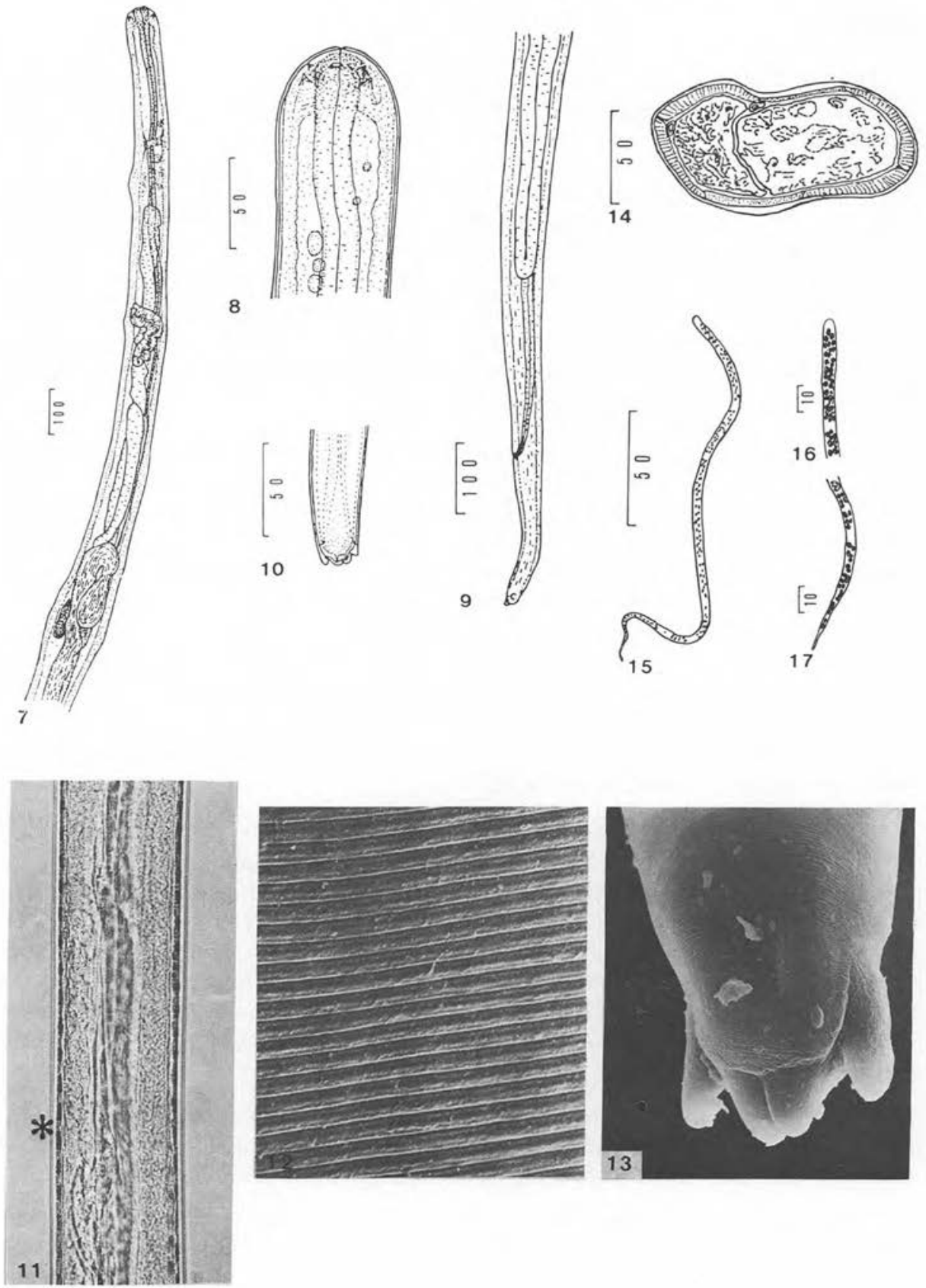

Fig. 7-1 7 . 


\section{Description}

Onchocercidae (Leiper, 1911) Chabaud and Anderson, 1959; Onchocercinae Leiper 1911; Tetrapetalonema Faust, 1935; subgenus Tetrapetalonema Chabaud and Bain, 1976.

General in female and microfilaria: Adult females extremely slender and delicate. Body of uniform diameter throughout most of its length with prominent body dilatations (annular swellings), usually 5 at the anterior part (fig. 7). Cephalic portion smoothly rounded, preesophageal cuticular ring absent, and equipped with 4 pairs papillae and 1 pair conspicuous amphids (fig. 8). Esophagus long, narrow, not distinctly divided into muscular and glandular parts. Cuticle with minute transverse striations. Female tail moderately long, bearing 4 terminal lappets. Microfilaria lacking sheath, circulating in blood.

Female (4 gravid females and 3 fragments of females; $\mu \mathrm{m}$, figs. 7-14): Body length $61 \mathrm{~mm}$ to $84(76) \mathrm{mm}$ and width of midbody 110 to 192 (154). Nerve ring 295 to 346 (321) from anterior extremity. Esophagus 908 long. Vulva 624 to 767 (673) from anterior extremity (fig. 7). Tail 224 to 326 (288) long, tapering towards tip, curving ventrad with 2 pairs of terminal lappets ( $f i g$. 10). Width at anus 41 to 53 (49). The ratio of tail length to width at anus 5.5 to 6.7 ( $f i g .9$ ). At the posterior part subcuticular markings situated regularly (fig. 11). Transverse striations of cuticle 0.3 apart longitudinally as shown in figure 12 by SEM. Lappets consisting of 1 pair lateral lappets and 1 pair terminal lappets as shown in figure 13. Phasmidial pores situated at the upper armpit of the lateral lappets. At cross-sections of midbody the broad lateral cords present. One pair of uterus containing microfilariae. Small oviduct and intestine stiuated ( $f$ ig. 14).

Microfilaria (10 specimens in blood films, fig. 15-17): Body 191.1 to 219.7 (205.1) long, 2.9 to 3.9 (3.4) wide at the maximum ( $f i g .15$ ). Cephalic space 3 to 7 (mean value $5 \mu \mathrm{m}, 2.5 \%$ of body length), nerve ring 35 to $44(42,20.3 \%)$, excretory pore 57 to $65(61,29.8 \%)$, excretory cell 64 to $86(70,34.3 \%), G_{1}$ cell 126 to $151(138,67.2 \%)$, anal pore 152 to $172(160,78.2 \%)$, last tail cell 183 to $202(196,95.5 \%)$. At the head space 1 pair minute spots situated. Presence of nuclei at the area rare (fig. 16). At the posterior part, 11 nuclei situated in 2 rows after anal pore, and then 7 nuclei in 1 row. The last tail nucleus slender. The terminal end part without nucleus slender and short 9.3 to $13(4.5 \%$ ) (fig. 17).

Microfilariae taken out from uterus of the females, without staining, 210 to 233 long and 3.1 to 4.4 wide. One small refractive spot situated at the terminal end, but unrecognizable in stained specimens. Tail ending with delicate bending.

In a thick film with blood containing living microfilariae, the microfilariae small, winding. Body length 127 to 174 (147), width 2.6 to 2.9 . Nerve ring 31 to $39(24 \%)$, excretory pore 45 to $52(33 \%)$, and anal pore 108 to $140(84 \%)$ from anterior extremity, respectively. 


\section{Discussion}

When $T$. akitensis was compared with the other species within the subgenus Tetrapetalonema, it resembled $T$. interstitium of the grey squirrel and $T$. llewellyni of the raccoon in North America in the female length and the shape of the terminal end of microfilariae (Price, 1962; Chabaud and Bain, 1976; Faust, 1935; McCoy, 1936; Nagaty, 1935; Eberhard, 1978). However, the esophagus of $T$. akitensis was nearly three times longer than $T$. interstitium and $T$. llewellyni. Moreover, $T$. llewellyni, the only one known species infecting the carnivorous host Procyon lotor in the present subgenus, could be distinguished from $T$. akitensis by its larger microfilaria. $T$. dunni, infecting Tupaia in southeastern Asia, was relatively smaller than $T$. akitensis in the female length (Mullin and Orihel, 1972). But, the microfilaria of T.dunni showed the terminal tip without nucleus as well as seen in the microfilaria of $T$. akitensis.

On the other hand the microfilariae of the other members of the subgenus, which infected monkeys (Platyrhini) in Central or South America, possessed the terminal nucleus at the tail end, so far described in the respective original paper (Faust, 1935; McCoy, 1936; Dunn and Lambrecht, 1963; Nagaty, 1935; Eberhard, 1978; Esslinger and Gardiner, 1974; Esslinger, 1966, 1979, 1981).

Body dilatations (swellings) appear to be useful indicators for grouping species in adult specimens within the subgenus. The features, as seen in $T$. akitensis, have been reported in the following species: T. dunni, T. marmosetae, T. atelensis, T. obtusa, T. tamarinae and T. mystaxi (Faust, 1935; McCoy, 1936; Esslinger, 1966; Dunn and Lambrecht, 1963; Eberhard, 1978). They seem to be present also in $T$. interstitium and $T$. llewellyni in their original drawings (Price, 1962), while, they were not present in $T$. barbascalensis, $T$. parvum, $T$. saimiri and $T$. panamensis in thissu bgenus (Esslinger and Gardiner, 1974; McCoy ,1936; Esslinger, 1981, 1979).

\section{(2) Dipetalonema (Chenofilaria) japonica sp. n. (fig. 18-22)}

Type specimen

Holotype: Nishiki No. 1 (female).

Muséum National d'Histoire Naturelle

Laboratoire de Zoologie, Paris. No. 263 NE.

Host: Selenarctos thibetanus japonicus.

Locality: Nishiki, Akita, Japan.

Site of infection: Adipose tissue around stomach.

\section{Description}

Onchocercidae (Leiper, 1911) Chabaud and Anderson, 1959; Onchocercinae Leiper, 1911; Dipetalonema Diesing, 1861; subgenus Chenofilaria (Kou, 1958).

Female (only 1 gravid female; $\mu \mathrm{m}$, figs. 18-21): Female adult short, slender with slightly rounded anterior portion. Cephalic extremity slightly attenuated, bearing 

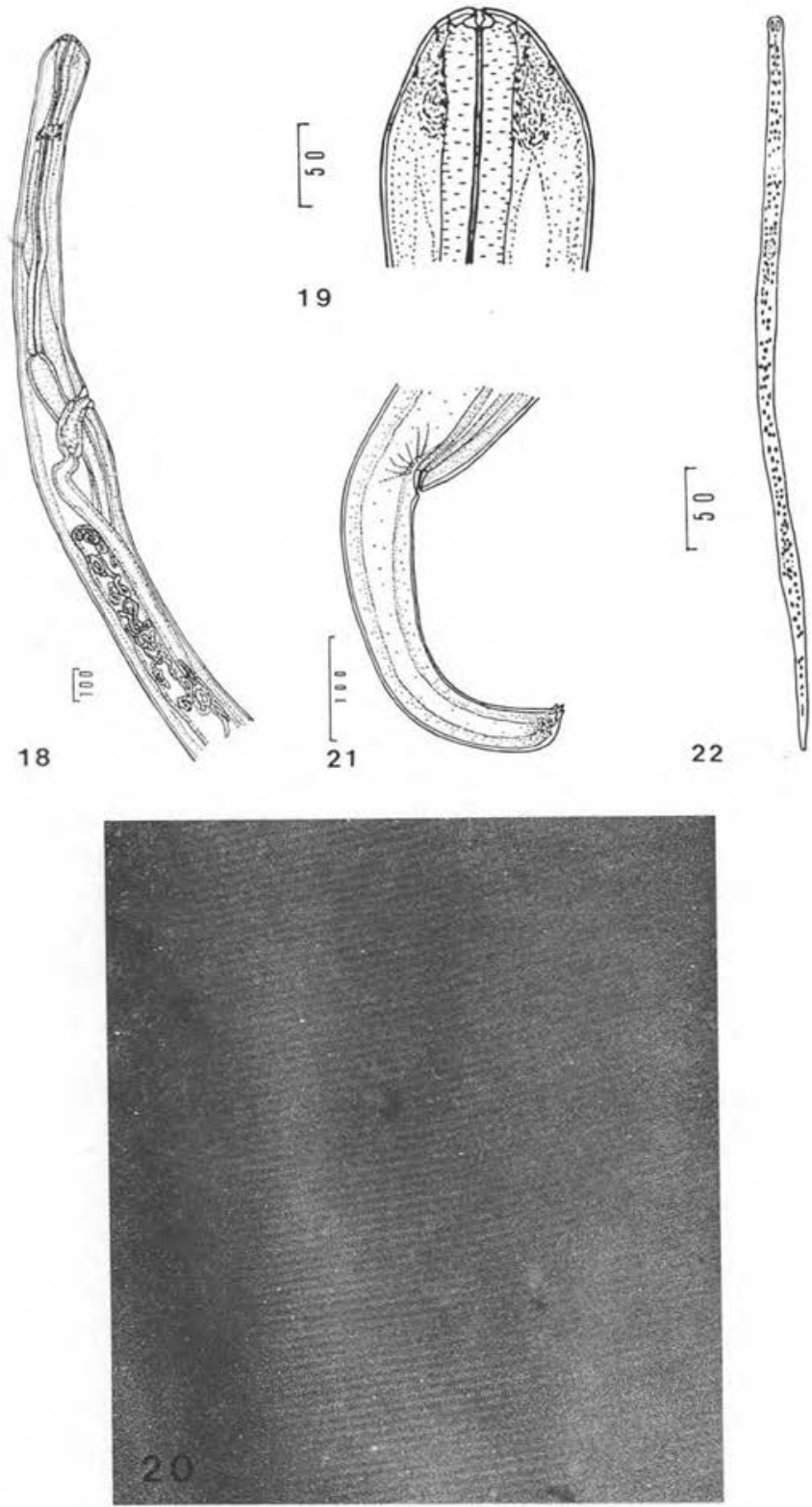

Fig. I8-22. - Dipetalonema (Ch.) japonica sp. n.

18. Anterior of female.

19. Cephalic extremity of female showing salient preesophageal cuticular ring. 20. Transverse striations of cuticle by metallurgical microscopy. $\times 900$.

21. Posterior of female.

22. Microfilaria. 
4 pairs papillae and 1 pair amphids. Body dilatation at the level just posterior to vulva (fig. 18). Buccal capsule small, surrounded by thickened preesophageal cuticular ring ( fig. 19). The internal lumen of esophagus covered by delicate chitinous wall. Esophagus not divided into anterior muscular and posterior glandular portions. Cuticle with transverse striations as shown in figure 20 by metallurgical microscopy. Body length $51 \mathrm{~mm}$, width at nerve ring 127, at vulva 209, at dilatate level 255, and at midbody 170 . Nerve ring 294 from anterior extremity, esophagealintestinal junction 998 and vulva $1.16 \mathrm{~mm}$. Tail 305 long, curving ventrad, slightly attenuated, terminating in 4 narrow, conical protuberances. Width at anus 74; ratio of tail length to width at annus 4.1. Anus surrounded by cuticular ring (fig. 21).

Microfilaria: Coiled stage of microfilaria in utero showed more than 300 long and 10 wide.

In a blood film of the host, from which the present female specimen was collected, only one microfilaria was found; 420 long and 10 wide (fig. 22). Head clear space 13 $(3.1 \%$ of body length) long, including 1 pair of salient chitinous apparatus. Distance from anterior extremity to nerve ring $80(19 \%)$, excretory pore $112(26.7 \%)$, excretory cell $137(32.6 \%), \mathrm{G}_{1}$ cell $250(59.5 \%)$, anal pore $345(82.1 \%)$, and last tail cell 397 $(94.5 \%)$. Thus, this microfilaria of the blood film appears to correspond to the microfilaria of Dipetalonema (Ch.) japonica sp. n.

\section{Discussion}

Within subgenus Chenofilaria, four species were described; D. (Ch.) filaria, D. (Ch.) johnstoni, D. (Ch.) pearsoni and D. (Ch.) fausti (Chabaud and Bain, 1976; Anderson and Bain, 1976; Kou, 1958; Mackerras, 1954; Spratt and Varughese, 1975; Esslinger, 1966). Recently, D. fausti was mentioned by Chabaud and Bain (1976) as the synonym of $D$. (Ch.) filaria described by Kou (1958). D. japonica sp. n. was similar to $D$. johnstoni at its body length, the undivided esophagus and the cervical body dilatation, but distinguishable by its longer tail and the salient cuticular ring around buccal capsule. D. pearsoni from Australia was also similar to D. japonica due to its undivided esophagus and the cervical dilatation, but different from D. japonica in its longer body length, almost twice (Spratt and Varughese, 1975). D. filaria or $D$. fausti differed from $D$. japonica because of their smaller bodies without the cervical body dilatation, and the divided esophagi with longer length.

The microfilaria in the blood (fig. 22), assumed to be D. japonica, was much larger than that of $D$. johnstoni or D. fausti (undescribed for D. pearsoni by Spratt and Varughese, 1975.) The microfilaria of D. johnstoni differed from the present microfilaria because of its forked tail tip. According to Spratt and Varughese (1975), the microfilariae of $D$. johnstoni were found occasionally in small numbers in the blood, even though they predominantly occurred in the skin of the host animals. In the present case, the finding of only one microfilaria in the blood during repeated searches suggests the possibility of its main distribution in the skin.

Pais Caeiro (1959) reported four kinds of microfilariae from Pholidota, Manis tricuspis in Angola. The present microfilaria from the bear showed close similarity 
to $M f$. vilhenae and $M f$. lundae in body length and lack of sheath. However, the present microfilaria was distinguishable from $M f$. lundae by the lack of terminal nucleus and from $M f$. vilhenae by the lack of subterminal nucleus. Although long well-stained helical fibers at the head space of $M f$. lundae were mentioned in his text, they seem to be different from the refractive chitinous apparatus of the present microfilaria. A well-stained area was shown in the center of the body of $M f$. vilhenae, but such an area was unrecognizable in the present microfilaria stained by Giemsa's stain. The refractive apparatus at head of the present microfilaria (fig. 22) may suggest the primordial features of the preesophageal cuticular ring of the adult D. japonica (fig. 19).

\section{3 - Prevalence of filarial parasites of bears in Japan}

The microfilariae of $D$. ursi were found in greater numbers from 2 adult black bears in Hyogo and Kyoto, the western part of the main island of Japan (fig. 1). No other microfilaria was found in their blood smears examined. One young bear (probably one year old) showed no filarial infection.

The blood smears of 64 black bears of Akita, the northern part of the main island of Japan, revealed that $T$. akitensis sp. n. infected 41 bears $(64.1 \%)$ and D. (Ch.) japonica sp. n. infected only one (1.6\%). The infection of $D$. ursi was not found in the dissections of the tissues and the blood smears.

No filarial infection was found in the examination of the blood smears of 5 brown bears, $U$. arctos yesoensis, kept in the bear park in Noboribetsu, Hokkaido, the northern island of Japan. The brown bears are natural inhabitants of Hokkaido island, where no Japanese black bears inhabit. (The blood smears were sent to me by Mr. Goda, the veterinarian of the park.)

\section{General discussion}

In the comparison of $D$. ursi from Japan and North America, the measurements showed the close affinities between the adults of them. The cervical dilatation of the adult specimens was found in all specimens examined irrespective of the differences of the species and habitats of the host animals. According to Rausch (1961), the only one D. ursi was found in all 219 American black bears examined by him in Alaska, but it was a common species in the brown bears. In the present case $D$. ursi was found in the bears inhabiting the western part of the main island of Japan, while it was not found in the bears of Akita, the northern part of the main island. This suggests the differences in host or vector susceptibility. The microfilaria of $D$. ursi was closely similar to that of $T$. akitensis, while the former was $20 \mu \mathrm{m}$ longer than that of the latter. Further, the length of terminal end part without nuclei was three times longer in D. ursi than that of T. akitensis (fig. 6 and 17). One pair of nuclei was frequently present at the cephalic space of the microfilaria of $D$. ursi, while there was only one or no nucleus in the microfilaria of T. akitensis (fig. 5 and 16). 
As a result of the comparison with other species of subgenus Tetrapetalonema, it seems that $T$. akitensis from bears of Japan suggests the closer affinities to the species of North America than to the species from monkeys of Central or South America. In the subgenus Chenofilaria, D. (Ch.) japonica from bears of Japan suggests the closer similarities to the species from marsupials of Australia than to the species from Pholidota of China. These findings should be useful in clarifying the expansion routes of the subgenera in the processes of the evolution of the genus Dipetalonema, sensu lato (Chabaud and Bain, 1976).

Acknowledgements: The author wishes to thank Professor S. Takada for his review of the manuscript. The author is also grateful to Dr. C. Shoho for his helpful suggestions, and to Mr. I. Kimata for making the histological preparations.

\section{REFERENCES}

Anderson R. C.: Description and relationships of Dirofilaria ursi Yamaguti, I94I, and a review of the genus Dirofilaria Railliet and Henry, I91 I. Trans. R. Canad. Inst., 1952, 29, 35-65.

Anderson R. C., BaIn O.: CIH keys to the nematode parasites of vertebrates. No. 3 . Keys to genera of the order spirurida. Part. 3. Diplotriaenoidea, Aproctoidea and Filarioidea, 1976, 59-I 6.

Chabaud A. G., Anderson R. C.: Nouvel essai de classification des filaires (superfamille des Filarioidea), II. Ann. Parasitol. Hum. Comp., I959, 34, 64-87.

Chabaud A. G., Bain O.: La lignée Dipetalonema. Nouvel essai de classification. Ann. Parasitol. Hum. Comp., 1976, s1, 365-397.

Chitwood M. B., Lichtenfels J. R.: Identification of parasitic metazoa in tissue sections. Exp. Parasitol., 1972, 32, 407-519.

DUNN F. L., LAMBRECHT F. L.: On some filarial parasites of South American primates, with a description of Tetrapetalonema tamarinae $\mathrm{n}$. sp. from the Peruvian tamarin marmoset, Tamarinus nigricollis (Spix, 1823). J. Helminthol., 1963, 37, 261-286.

EBERHARD M. L.: Tetrapetalonema (T.) mystaxi sp. n. (Nematoda: Filarioidea) from Brazilian moustached marmosets, Saguinus m. mystax. J. Parasitol., 1978, 64, 204-207.

Esslinger J. H.: Dipetalonema fausti sp. n. (Filarioidea: Onchocercidae), a filarial parasite of the scaly anteater, Manis pentadactyla L. (Pholidota), from China. J. Parasitol., I966, 52, 494-497.

Esslinger J. H.: Dipetalonema obtusa (McCoy, 1936) comb. n. (Filarioidea: Onchocercidae) in Colombian primates, with a description of the adult. J. Parasitol., 1966, 52, 498-502.

Esslinger J. H. : Tetrapetalonema (T.) panamensis (McCoy, 1936) comb. n. (Filarioidea : Onchocercidae) in Colombian primates, with a description of the adults. J. Parasitol., I979, 6s, 924-927.

Esslinger J. H.: Tetrapetalonema (T.) saimiri sp. n. (Nematoda: Filarioidea) from Colombian squirrel monkeys, Saimivi sciureus. J. Parasitol., 1981, 67, 268-271.

ESSLINGER J. H., GARDINER C. H.: Dipetalonema barbascalensis sp. n. (Nematoda: Filarioidea) from the owl monkey, Aotus trivirgatus, with a consideration of the status of Parlitomosa zakii Nagaty, 1935. J. Parasitol., 1974, 60, 1001-1005.

FAUST E. C.: Notes on helminths from Panama. III. Filarial infection in the marmosets, Leontocebus geofroyi (Pucheron) and Saimiri örstedii örstedii (Reinhardt) in Panama. Trans. Roy. Soc. Trop. Med. Hyg. 1935, 28, 627-634.

Johnston T. H., Mawson P. M.: An account of some filarial parasites of Australian marsupials. Trans. R. Soc. S. Aust., 1938, 62, 107-121.

Kou C. C.: Studies on parasitic nematodes of mammals from Canton. I. Some new species from Paradoxurus minor Schwarz, Paguma larvata larvata (Hamilton Smith) and Manis pentadactyla aurita Hodgson. Acta Zool. sin., Peking, 1958, 10, 60-72.

Lent H., Teixeira DE Freitas J. F.: Contribuicao ao estudo do genero Dirofilaria Railliet and Henry, r9I I. Mem. Inst. Oswaldo Cruz., I937, 32, 37-54.

Mackerras M. J.: Two new species of Dipetalonema (Nematoda, Filarioidea) from Australian marsupials. Proc. Roy. Soc. Queensland, 1954, 64, 5I-56.

McCoy O. R.: Filarial parasites of the monkeys of Panama. Am. J. Trop. Med., 1936, 16, $383-403$.

Mullin S. W., ORIHEL T. C.: Tetrapetalonema dunni sp. n. (Nematoda: Filarioidea) from Malaysian tree shrews. J. Parasitol., 1972, \&8, ro47-1051. 
Nagaty H. F.: Parlitomosa zakii (Filariinae), A new genus and species and its microfilaria from Leoncebus rosalia. J. Egypt. Med. Assoc., 1935, I8, 483-496.

Pais CAeIro V. M.: Quatro espécies de microfilàrias do Phataginus Manis tricuspis (Rafinesque). An. Escola Superior Med. Vet., Lisbon, 1959, 2, 83-94.

Petrov A. M., Krotov A. I.: (On the discovery of Dirofilaria ursi Yamaguti, I94I in the subcutaneous tissue of thorax of a bear.) Trudy Gelmint. Lab. Akad. Nauk., (U.S.S.R.), I954, 7. $335-336$ (in Russian).

PrICE D. L.: Dirofilaria magnilarvatum n. sp. (Nematoda: Filarioidea) from Macaca irus Cuvier. I. Description of the adult filarial worms. J. Parasitol., 1959, 45, 499-504.

PRICE D. L.: Description of Dipetalonema interstitium n. sp. from the grey squirrel and Dipetalonema llewellyni n. sp. from the raccoon. Proc. Helm. Soc. Wash., 1962, 29, 77-82.

RAUSCH R. L.: Notes on the black bear, Ursus americanus Pallas, in Alaska, with particular reference to dentition and growth. Z. Säugetierk., 1961, 26, 77-107.

Rogers L. L., Rogers S. M.: Parasites of bears, A review, 4II-430. in "Bears-their biology and management". 3rd International Conference on bears, International Union for Conservation Natural Resources, 1976, No. 40, Switzerland.

Sноно C., UNi S.: Scanning electron microscopy of some Setaria species (Filarioidea, Nematoda). Z. Parasitenk., 1977, 53, 93-104.

SonrN M. D.: (Filariata of animals and man and the disease caused by them. Part. 3. Filarioidea: Filariidae and Onchocercidae). In: Ryzhikov, K. M. [ed.], "Osnovy Nematodologii", 24. Moscow Acad. Nauk U.S.S.R., 1975 (in Russian).

SPRATT D. M., VARUghese G.: A taxonomic revision of filarioid nematodes from Australian marsupials. Aust. J. Zool. Suppl. Ser., I975 (No. 35), I-99.

UNI S.: Scanning electron microscopic study of Dirofilaria species (Filarioidea, Nematoda) of Japan and a review of the genus Dirofilaria. J. Osaka City Med. Center, 1978, 27, 439-458 (in Japanese).

WorLEY D. E., Winters J. B., GREeR K. R.: Helminth and arthropod parasites of grizzly and black bears in Montana and ajdacent area. 455-464, in "Bears-their biology and management". 3rd International Conference on bears, International Union for Conservation Natural Resources, 1976, No. 40, Switzerland.

YamagurI S.: Studies on the helminth fauna of Japan. Part 35. Mammalian nematodes II. Jap. J. Zool., r941, 9, 409-439. 